\section{AL-AZHAR}

Assiut Dental Journal
The Official Publication of The

Faculty of Dental medicine.

Al-Azhar Assiut Uniuersity.

AADJ, Vol. 3, No. 1, April (2020) - PP. 19:24

ISSn 2682-2822

\title{
Effect of Dentin Desensitizing Agents on Shear Bond Strength of Two Total-Etch Adhesive Systems
}

\author{
Ahmed A. Abd El-ghany"1
}

Codex : 03/2020/04

Aadj@azhar.edu.eg

\section{KEYWORDS}

Shear, Desensitizing Agents,

Total Etch Adhesives,

Dentine, Bond Strength.
1. Department of Operative Dentistry, Faculty of Dental Medicine (Boys), Assiut, Al-Azhar University, Egypt.

* Corresponding Author e-mail: ahmedata@azhar.edu.eg

\begin{abstract}
Aim: it is to evaluate the effect of dentine desensitizing agents on shear bond strength of two totals-etch adhesive systems. Subjects and methods: Sixty human premolars free from caries or cracks were used in the study and randomly divided into six groups, group1; Adper Single bond 2, group 2; Prime \& Bond NT, Group3; Adper Single Bond and Gluma desensitizing agent, group4,Adper Single Bond 2 and Vivasens desensitizer, group5;Prime\& Bond NT and Gluma desensitizer, group 6; Prime\& Bond and Vivasens, then Z250 XT nanohybrid composite resin was packed in the mould and cured, then shear bond strength was measured by INSRTON universal testing machine, One-way ANOVA and Turhey's tests were used for statistical analysis ( $\mathrm{P}$ value $\leq 0.05)$. Results: group 3 Adper single bond 2 and Gluma registered the highest mean shear bond strength value (12.806 \pm 0.89$)$, followed by group 1: Adper Single bond2 registered (12.046 \pm 0.84 ), group 2; Prime \& Bond NT recorded (11.21 \pm 0.47$)$, group 4 , Adper Single bond 2 and Gluma registered (11.1435 \pm 0.54 ), group 5, Prime $\&$ Bond and Gluma registered $(11.818 \pm 0.56)$, and group 6, Primr \& Bond and Vivasens recorded (11.0485 \pm 0.54$)$. Conclusion: Gluma improved shear bond strength with both tested total-etch adhesive systems.
\end{abstract}

\section{INTRODUCTION}

Composite resin restorations have been extensively used in both anterior and posterior restorations, in anterior teeth due its esthetic and mechanical properties and in posterior teeth because of its esthetic characteristics and improved mechanical properties it became an alternative to amalgam restorations in posterior teeth.

Bonding to enamel is depending on micromechanical retention between resin and inorganic structure of enamel, but bonding with dentine is comparatively difficult, that due to the complex structure of dentine and the lower content of inorganic structures than enamel and also presence of water in dentinal fluids.After acid etching of dentine and removal of the inorganic supporting structure leaving the collagen matrix easily shrinks and collapsed ${ }^{(1)}$ with air drying, so wet bonding 
technique was recommended to preserve the micro morphological integrity of collagen and many studies ${ }^{(2-3)}$ supporting the wet bonding technique as it allowing penetration of resin to the matrix forming higher bond strength.

Post-operative sensitivity still forming complain to patients, so desensitizing agents appeared to decrease the post -operative sensitivity and rewetting the matrix after etching (4-6). The current study will evaluate the effect of desensitizing agents on shear bond strength of total etch bonding agents.

\section{MATERIALS AND METHODS}

Sixty sound human premolars were collected during (2-3 weeks) for the current study. Patients average age was $(35 \pm 5)$, the teeth were extracted periodontic and orthodontic reasons, and stored in distilled water till time of testing procedure.

Teeth were free from any caries or cracks, ultrasonic scalling to remone any debris and calculus. Teeth were randomly divided into 6 groups. Each tooth was embedded at cement-enamel junction in chemically cured acrylic resin block its dimension was $15 \mathrm{~mm}$ diameter and $20 \mathrm{~mm}$ height.

Table (1): The used materials in the study

\begin{tabular}{|c|c|c|c|}
\hline Material & Type & Composition & Manufacturer \\
\hline 1- Gluma & Desensitizing agent & $\begin{array}{l}\text { - } 36.1 \% \text { HEMA (2-hydroxyl ethyl meth- } \\
\text { acrylate). } \\
\text { - } 5.1 \% \text { glutraldehyde, water }\end{array}$ & Heraeus, Kulzer, Germany \\
\hline 2-Vivasens & Desensitizing agent & $\begin{array}{l}\text { Ethanol, water, and hydroxypropyl cel- } \\
\text { lulose with potassium fluoride, polyeth- } \\
\text { ylene glycol dimethacrylate. }\end{array}$ & $\begin{array}{l}\text { Ivoclar } \quad \text { Vivadent, } \\
\text { Amherst, NY, USA }\end{array}$ \\
\hline $\begin{array}{l}\text { 3-Adper Single Bond } \\
2\end{array}$ & $\begin{array}{l}5^{\text {th }} \text { generation bond- } \\
\text { ing agent }\end{array}$ & $\begin{array}{l}\text { BisGMA, HEMA, di-methacrylates, } \\
\text { ethanol. Water, photoinitiator system } \\
\text { methacrylate functional copolymers }\end{array}$ & $\begin{array}{l}\text { 3M ESPE, Dental prod- } \\
\text { ucts, Paul, MN. USA }\end{array}$ \\
\hline 4- Prime \&Bond NT & $\begin{array}{l}5^{\text {th }} \text { generation bond- } \\
\text { ing agent }\end{array}$ & $\begin{array}{l}\text { - PENTA (dipentaerythritol penta-acry- } \\
\text { late monophosphorous acid ester } \\
\text { - UDMA (urethane dimethacrylate } \\
\text { - Butylated hydroxytoluene } \\
\text { - 4-Ethyl dimethacrylate amino penzoate } \\
\text { - Cetylamine hydroxyflouride } \\
\text { - Silica nano filler } \\
\text { - Camphorquinone } \\
\text { - Solvent, Acetone. }\end{array}$ & Dentsply, Caulk USA \\
\hline 5- Z250 XT & $\begin{array}{l}\text { Nano-hybrid com- } \\
\text { posite resin }\end{array}$ & $\begin{array}{l}\text { Bis-GMA,UDMA, } \\
\text { bis-EMA, PEGDMA, and TEGDMA res- } \\
\text { ins, Nanohybrid }\end{array}$ & $\begin{array}{l}\text { 3M ESPE, Dental prod- } \\
\text { ucts, Paul, MN. USA }\end{array}$ \\
\hline
\end{tabular}


Horizontal sectioning by diamond disc (FIEFICO, Geneva city, Switzerland) with coolant below the dentinoenamel junction to expose dentine surface without any remnants of enamel on the occlusal surface of the specimens, the grouping of the specimens into six groups $(\mathrm{n}=10)$ as the following order, group 1; Adper Single bond (3M ESPE), $5^{\text {th }}$ generation bonding agent as control group 1, group 2, Prime \& Bond NT (Dentsply, Caulk, USA), $5^{\text {th }}$ generation bonding agent control group 2. Group 3, Adper single bond and Gluma desensitizing agent (Heraeus, Kulzer, Germany), group 4, Prime \& Bond and Vivasens desensitizing agent, group 5, Adper singlebond and Vivasens, group 6, Prime \& Bond and Vivasens .

Etching of dentine of all teeth for 15 seconds with $37 \%$ phosphoric acid Scotchbond etchant (3 M ESPE),rinsing for 5 seconds and drying leaving dentin surface slightly wet, and in group 1, Adper Single Bond 2 was placed by micro brush and cured for 20 seconds by LED curing unit (Woodpecker TMFreelightTM 2 St. Paul,MN, USA) . in group 2, Prime and Bond NT was placed by microbrush and cured with LED curing unit (Woodpecker TMFreelightTM 2 St. Paul,MN, USA), in group 3 after etching and rinsing, dryness and Gluma applied to dentine surface by pumping motion using micro brush for 60 seconds, then Adper Single Bond application and curing for 20 seconds by LED curing unit, the same in group 4 with Vivasens desensitizing agent placed with by micro brush in pumping motion for 60 seconds, then Adper Single Bond2 placed by microbrush and cured for $20 \mathrm{sec}-$ onds by LED curing unit.

In group 5, Gluma application by pumping motion for 60 seconds with microbrush for 60 seconds, then Prime\& Bond NT is placed and curing for 20 seconds by LED curing unit, in group 6 similar to group 5 but using Prime \& Bond NT and Vivasens desensitizing agent.
A plastic translucent tube was used as a mould (Henso Medical Co. Ltd. China) to pack composite resin inside it of dimension $4 \mathrm{~mm}$ internal diameter and $2 \mathrm{~mm}$ height, Z250 XT nanohybrid composite was packed to fill the plastic mould and cured for 20 seconds by LED curing unit, then removal of plastic tube by scalpel No. 15, then measuring the shear bond strength by INSTRON universal testing machine (Limited, Birmingham city, England), Figure (1), the data is statistically analyzed by using Oneway ANOVA test and Turkey's Honest Difference (THD), $(\mathrm{p} \leq 0.05)$.

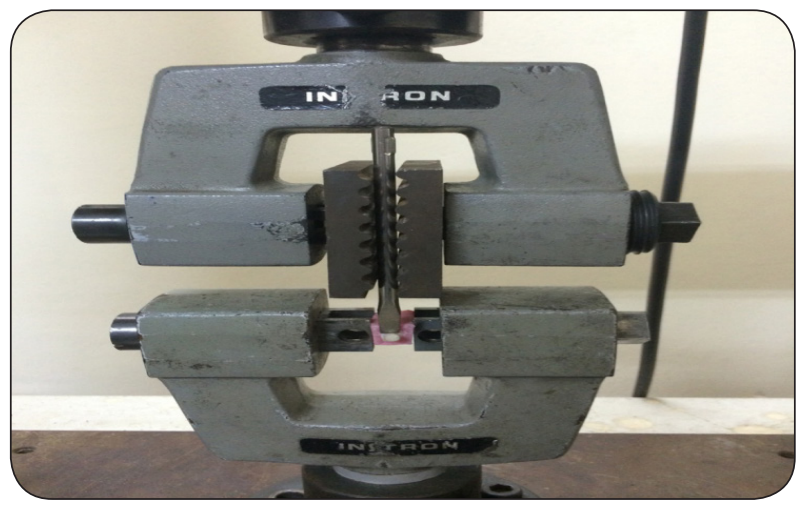

Fig. (1) Specimen under INSTRON universal testing machine.

\section{RESULTS}

The mean value of shear bond strength revealed that Adper single bond registered the highest value when Gluma desensitizing agent added with slight difference than Adper single bond in control group without signisicant difference. In both control groups Adper Single Bond recorded significantly higher shear bond strength value than Prime \& bond NT, Vivasens decreased mean value of shear bond strength in both Adper Single Bond and in Prime \& Bond groups but with significant difference in Adper Single bond and without significant difference in Prime \& Bond group. Gluma desensitizing agent could improve shear bond strength significantly with Prime \& Bond NT groups, as shown in Table (2). 
Table (2): The mean value of shear Bond strength (Mpa)

\begin{tabular}{|c|c|c|c|}
\hline & Control group & Gluma desensitizing agent & Vivasens desensitizing agent \\
\hline Adper Single Bond & $12.046^{\mathrm{a}} \pm 0.84$ & $12.806^{\mathrm{a}} \pm 0.89$ & $11.1435^{\mathrm{b}} \pm 0.54$ \\
\hline Prime \& Bond NT & $11.21^{\mathrm{b}} \pm 0.47$ & $11.818^{\mathrm{a}} \pm 0.56$ & $11.0485^{\mathrm{b}} \pm 0.54$ \\
\hline
\end{tabular}

$(P$ value $\leq 0.05)$

\section{DISCUSSION}

Nowadays composite resin restorations are extensively used performing function and esthetic even in posterior teeth, total etch bonding procedures are very sensitive technique as after etching presence of over wetted dentin surface decreasing bond strength and dry bonding doesn't permit sufficient penetration of resin to form hybrid layer, so desensitizing agents can added to rewet dentin surface after dryness and it decreases post-operative sensitivity $^{(7)}$.

Many studies mentioned that bonding with dentin moist surface achieving higher shear bond strength, but the risk of over wetting is presence of excessive water which causing phases separation of hydrophilic and hydrophobic monomers components ${ }^{(3)}$ that leads to globule and blister formation at dentin-resin interface, so rewetting by desensitizing agent can improve shear bond strength as Gluma desensitizers improved shear bond strength of both Adper single bond and Prime \& Bond NT that in agreement with Soares ${ }^{(8)}$, Ritter ${ }^{(9-10)}$, and Banasal (11). Vivasens gave slightly lower shear bond strength than control group that in agreement with Lehman and Degrange. HEMA in Gluma desensitizing agent improved adhesion between ester group and dentin collagen and decreased shrinkage of resin forming better shear bond strength and that explain Gluma positive effect in the current study.
The low effect of Vivadent on shear bond strength in this study in agreement with Lehmann ${ }^{(12)}$ it may due to blocking of dentinal orifices and interdiffusion channels as it contains fluorides. It is clear that ethanol based bonding agents gave better results than acetone based because of acetone higher volatile property which reaching $200 \mathrm{~mm} \mathrm{Hg}$ compared with only $54.1 \mathrm{~mm} \mathrm{Hg}$ of ethanol ${ }^{(11)}$, and high concentration of acetone which reaching $70 \%$ so not permitting formation of a uniform film covering dentin surface.

\section{CONCLUSION}

Ethanol based bonding systems give better shear bond strength, and Gluma can improve shear bond strength.

\section{REFERENCES}

1. Nakabayashi N, Pashley DH. Hybridization of dental Tissues. Che.3,1,2 Tokyo: Quintessence publishing co Ltd; 1998.

2. Kanca $\mathbf{J}$ 3rd. Resin bonding to wet substrate. 1. Bonding to dentin Quintessence Int 1992;23:39-41.

3. Al Qahtani MQ, Platt JA, Moore BK, Cochran MA. The effect of rewetting dry dentin with two desensitizers on shear bond strength. Oper Dent, 2003;28;267-96.

4. Pilo R, Cardash HS, Oz-Ari B, Ben-Amar A. Effect of preliminary treatment of the dentin surface on the shear bond strength of resin composite to dentin. Oper Dent 2001;26:569-75. 
5. Perdigão J, Van Meerbeek B, Lopes MM, Ambrose WW. The effect of a re-wetting agent on dentin bonding. Dent Mater 1999;15:282-95.

6. Perdigão J, Swift EJ Jr, Heymann HO, Malek MA. Effect of a re- wetting agent on the performance of acetone-based dentin adhesives Am J Dent.1998;11:207-13.

7. Lopes GC. Shear bond strength of acetone based one bottle system adhesive. Braz Dent J 2006;17(1):39-43.

8. Soares CJ, Santos Filho PC, Barreto BC, Mota AS. Effect of previous desensitizer and rewetting agent application on shear bond strength of bonding systems to dentin. Cienc odontol bras 2006;9(4):6-11.
9. Ritter AV, Bertoli C, Swift EF Jr. Shear Bond Strengths of Gluma Bonding Systems to Dentin. J Dent Res 2000; 79:1852.

10. Ritter AV, Heymann HO, Swift EJ Jr, Perdigão J, Rosa BT. Effects of different re-wetting techniques on dentin shear bond strengths. J Esthet Restor Dent 2000;12:85-96.

11. Bansal A, Shivanna V. Effect of Rewetting agents on the shear bond strength of different bonding agents when applied on dry dentin. J Conserv Dent 2007;10:26-32 .

12. Lehmann N, Degrange M. Effect of four desensitizers on the shear bond strength of three bonding systems. European Cells and Materials. 2005;9.Supp1(1):52-3. 


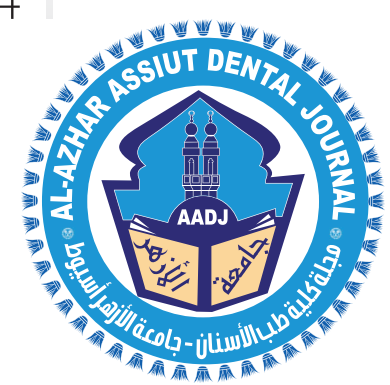

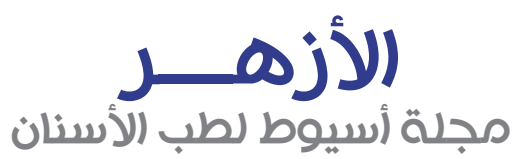

النشر الرسمي لكلية طب الأسنان

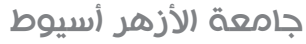

\title{
تأثير العوامل المانعة لتحسس العاج السنص علم قوة الإنه الرابط

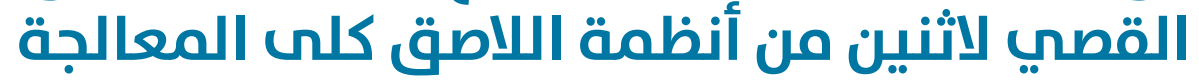

\author{
* أحمد عطى عبد الغنى عبد العال \\ 1. قسـم العلاج التحفظى ، كلية طب الاسنان (بنين ( اسيوط ، جامعة الازهر ، جمهورية مصر العربية \\ AHMEDATA @AZHAR.EDU.EG : البريد الإلكتروني: *
}

الملخص:

الهـدف : تهدف تلك الدراسة لتقييم تأثير العوامل المانعة لتحسـس العاج السنى على قوة الرابط القصي لاثنين من أنظمة اللاصق كلى المعالجة.

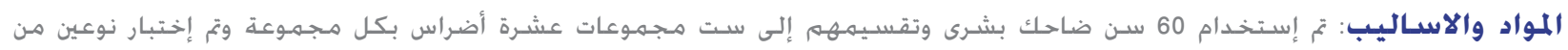

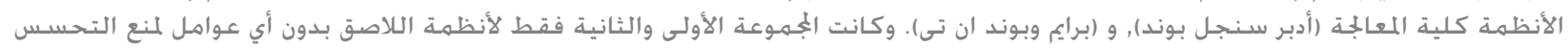

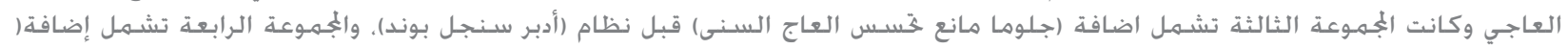

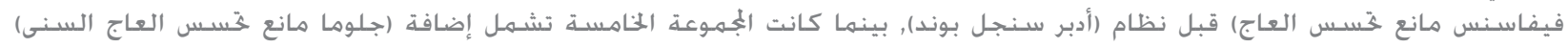

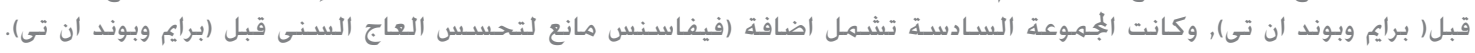

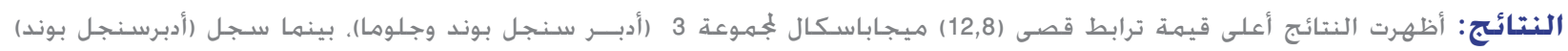

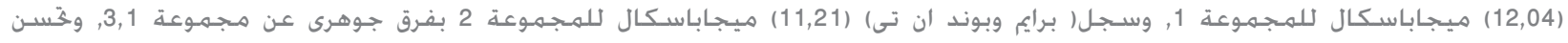

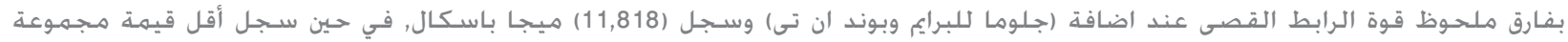
6(فيفاسنس هع برايم وبوند ان تى) وستجل (11,04) ميجاباسكال.

الخلاصة: إن مانعة التحسس حسنت قيمة الرابط القصي مع كلا من النظامين المختبرين للاصق كلى المعالجة الكلمات المفتاحية: الرابط القصي، عاج السنه ، اللاصق الكلى، قوة اللاصق ، خسين العاج السنى 